THE KURUME MEDICAL JOURNAL Vol. 18, No. 4, 1971

\title{
REACTION OF ANTIGENIC SUBSTANCE IN FECES OF RABBITS INFECTED WITH SCHISTOSOMA JAPONICUM*
}

\author{
KOYO OKABE, MINORU AKUSAWA AND TAMIKO HANAMURA \\ Department of Parasitology, Kurume University School of Medicine \\ Kurume, Japan
}

(Received for publication September 16, 1971).

\begin{abstract}
The existence of Schistosoma japonicum antigen was ascertained in feces of rabbits infected with $S$.japonicum by means of precipitin reaction between anti-S.japonicum rabbit serum. In some example, no positive reaction was found. This may be depend on the quantitative relation of antigen and antibody in such examples.
\end{abstract}

Morisita and Mabuchi (1957) reported that extracts prepared from feces of persons infected with intestinal parasites such as Ascaris, hookworms, cestodes, and intestinal trematodes will react with immune serum sensitized with the above mentioned parasites respectively. They named this reaction the T. M. reaction.

We prepared an extract from the feces of rabbits infected with Schistosoma japonicum and tested it against immune serum using the Ouchterlony's technique. We found a single precipitin band.

\section{MATERIALS AND METHODS}

1. Feces of rabbits infected with Schistosoma japonicum

Rabbits feces containing schistosome eggs were used. These rabbits were previously infected at 5, 8 and 12 months respectively. Also after infection feces of rabbits were tested from 13 days to
57 days. Feces of rabbits treated with niridazole 2 years ago and infected with Clonorchis sinensis were also tested.

2. Preparation of fecal extract

The feces were weighed and mixed with physiological saline solution (100 $\mathrm{g} / 300 \mathrm{ml}$ ), extracted at $6^{\circ} \mathrm{C}$ for 24 hours. The solution was filtered with gauze and centrifuged for 30 minutes at 12,000 r. p. m.

The resulting supernatant fluid was used as the antigen (coproantigen).

The complete procedure for extraction of antigen and final dilution are as follows :

A. Schistosome infected rabbits

1 Feces $100 \mathrm{~g}$ : saline $300 \mathrm{ml}$.

B. Schistosome treated rabbit

2 Feces $50 \mathrm{~g}$ : saline $200 \mathrm{ml}$.

3 Dilute supernatant fluid $(2 x)$ with saline

C. Clonorchis infected rabbits

4 Feces $41 \mathrm{~g}$ : saline $41 \mathrm{mI}$.

* This paper was read at the Joint Conference on Filariasis and Schistosomiasis, U. S. -

Japan Cooperative Medical Science Program in Bethesda, Maryland. (July 26-27, 1971) 
TABLE 1

Results of the experiments

\begin{tabular}{ccccccc}
\hline Rabbit & Worm & eggs & Date of & No. of & Duration & Results $\dagger$ \\
no. & in & infection & cercariae & A & B & Remarks \\
\hline
\end{tabular}

\begin{tabular}{|c|c|c|c|c|c|c|c|c|}
\hline \multicolumn{9}{|c|}{ Schistosoma japonicum } \\
\hline 1 & & May & 13,1970 & 3,000 & $12 \mathrm{~m}$. & + & & \multirow[t]{2}{*}{ Died in June; worms recovered } \\
\hline 2 & + & Sep. & 11,1970 & 2,500 & $8 \mathrm{~m}$ & \pm & + & \\
\hline 3 & & Dec. & 17,1970 & 3,000 & $5 \mathrm{~m}$ & + & & Died ; worms recovered \\
\hline $4-a$ & + & Apr. & 14, 1971 & 1,000 & $54 \mathrm{~d}$. & - & & \\
\hline $\mathrm{b}$ & & & & & $61 \mathrm{~d}$. & + & & \\
\hline $5^{-a}$ & & Apr. & 14,1971 & 1,000 & $41 \mathrm{~d}$ & - & - & \\
\hline b & & & & & $48 \mathrm{~d}$. & - & & \\
\hline c & + & & & & $57 \mathrm{~d}$ & - & + & \\
\hline 6 & + & Apr. & 22,1971 & 1,200 & $42 \mathrm{~d}$. & + & & \\
\hline 7 & + & Apr. & 22,1971 & 1,500 & $36 \mathrm{~d}$. & - & + & \\
\hline 8 & + & Apr. & 22,1971 & 1,200 & $39 \mathrm{~d}$. & + & & \\
\hline $9-\mathbf{a}$ & & May & 11, 1971 & 2,500 & $20 \mathrm{~d}$ & - & & \\
\hline $\mathrm{b}$ & & & & & $27 \mathrm{~d}$. & + & & Died ; worms recovered \\
\hline 10 & & May & 11,1971 & 2,500 & $20 \mathrm{~d}$ & + & & \\
\hline 11 & & May & 11, 1971 & 2,500 & $22 \mathrm{~d}$ & + & & \\
\hline $12-\mathbf{a}$ & & May & 11, 1971 & 2,500 & $18 \mathrm{~d}$. & - & & \\
\hline $\mathrm{b}$ & & & & & $25 \mathrm{~d}$. & - & & \\
\hline c & + & & & & $32 \mathrm{~d}$. & + & & Died ; worms recovered \\
\hline $13^{-a}$ & & May & 11,1971 & 2.500 & $18 \mathrm{~d}$. & - & & \\
\hline $\mathrm{b}$ & & & & & $25 \mathrm{~d}$. & - & & \\
\hline c & + & & & & $34 \mathrm{~d}$. & - & - & Autopsied on Jun. 28 ; worms (+) \\
\hline $14^{-a}$ & & May & 11,1971 & 2,500 & $20 \mathrm{~d}$. & - & & \\
\hline $\mathrm{b}$ & & & & & $27 \mathrm{~d}$ & \pm & & \\
\hline c & - & & & & $36 \mathrm{~d}$. & - & - & Autopsied on Jun. 28 ; worms $(+)$ \\
\hline $15^{-a}$ & & May & 11,1971 & 2,500 & $22 \mathrm{~d}$. & - & & \\
\hline $\mathrm{b}$ & & & & & $28 \mathrm{~d}$. & + & & Died on Jun. $25 ; 110$ worms \\
\hline 17 & + & May & 18,1971 & 3,000 & $15 \mathrm{~d}$. & + & & Died \\
\hline $18-a$ & & May & 18,1971 & 2,500 & $15 \mathrm{~d}$. & - & & \\
\hline $\mathrm{b}$ & & & & & $21 \mathrm{~d}$. & - & & \\
\hline $\mathrm{c}$ & - & & & & $28 \mathrm{~d}$. & - & - & \\
\hline $19-\mathbf{a}$ & & May & 18,1971 & 2,500 & $15 \mathrm{~d}$. & - & & \\
\hline $\mathrm{b}$ & & & & & $21 \mathrm{~d}$. & - & & \\
\hline $\mathrm{c}$ & & & & & $28 \mathrm{~d}$. & - & - & \\
\hline $20-\mathbf{a}$ & + & May & 18,1971 & 3,000 & $13 \mathrm{~d}$. & - & & \\
\hline $\mathrm{b}$ & & & & & $20 \mathrm{~d}$ & + & & \\
\hline 21 & + & & $?$ & $?$ & Jun. 22, '71 & + & & Blood in feces \\
\hline 32 & - & Nov. & 30,1967 & 1,100 & $\begin{array}{l}\text { May 25,'71 } \\
(3 y .6 \mathrm{~m} .)\end{array}$ & H & & $\begin{array}{l}\text { Treated with Ambilhar }(100 \\
\mathrm{mg} / \mathrm{kg}) \text { for } 7 \text { days (Feb. 1968) }\end{array}$ \\
\hline Clone & is $s$ & iensis & & & & & & \\
\hline 34 & & Jan. & 10,1970 & $2,500^{*}$ & $1 \mathrm{y} .6 \mathrm{~m}$. & + & & Died ; worms $(+)$ \\
\hline 35 & + & Nov. & 5,1970 & $517^{*}$ & $7 \mathrm{~m}$ & + & & \\
\hline Contr & Jni & ected) & & & & & & \\
\hline $36-40$ & - & & - & - & Jun. 25, '71 & - & & \\
\hline
\end{tabular}

* No. of metacercariae. †A : Ouchterlony's method; B : pH reactivation. 
3. Preparation of antiserum

Antiserum for precipitin reaction was obtained from rabbits immunized $(3 x)$ with lyophilized adult schistosomes using Freund's complete adjuvant. Its titer was $1: 10,000$ as determined by the ring precipitin test.

4. Ouchterlony's method

Twenty-five $\mathrm{ml}$ of $2 \%$ agar solution was poured into $8 \mathrm{~cm}$ petri dish and was cooled. The center well was used for antibody. The distance of the wells containing antigen was $4 \mathrm{~mm}$ from the center well. The reaction was observed for 7 days.

5. Acid reactivation of negative stool

In the case of fecal extracts with negative reaction in Ouchterlony's method, those extracts were acidified with $0.1 \mathrm{~N} \mathrm{HCl}$ at $\mathrm{pH} 2.2$, and then adjusted to neutrality with $0.1 \mathrm{~N} \mathrm{NaOH}$ for the purpose of dissociation of antigen antibody complex.

\section{RESULTS}

Fecal sample were obtained from 20 rabbits of which infection dates were various. These feces were separately extracted and subjected to the experiments as mentioned methods. Results are shown in Table 1.

The reaction of fecal examinations of the infected rabbits are summarized and 13 positive and 7 negative results were obtained as shown in Table 2. The antigen prepared from feces of infected rabbits treated with niridazole when tested at the original dilution using the Ouchterlony's technique did not show a reaction band. When this antigen was diluted $(2 \times)$ a single band was observed.

In rabbit of No. 17, the reaction was already positive 15 days after infection and many cases showed positive about 20 days after infection. The rabbit No. 1 , which had been long time after infection and was in a chronic phase, was also positive in this reaction.

TABLE 2

Reaction of fecal extracts by Ouchterlony's method

\begin{tabular}{|c|c|c|}
\hline Reaction & No. of rabbits & Total \\
\hline Positive & 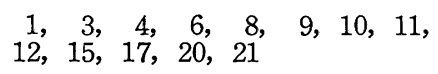 & 13 \\
\hline Negative & $7,13,14,18,19$ & 7 \\
\hline
\end{tabular}

\section{DISCUSSION}

Fecal saline extracts of rabbits infected with Schistosoma japonicum were used as an antigen and subjected to agar double diffusion between antiS. japonicum rabbit serum. Then, 13 out of 20 samples were positive in the reaction. Moreover, 3 of the 7 negetive samples turned to positive in acid reactivation which was supposed to be effective for the dissociation of antigen antibody complex (Table 3).

TABLE 3

Results of acid reactivation of the negative group

\begin{tabular}{lcc}
\hline Reaction & No. of rabbits & Total \\
\hline Positive & $2,5,7$ & 3 \\
Negative & $13,14,18,19$ & 4 \\
\hline
\end{tabular}


Fig. 1 Reaction of extracts of rabbits feces infected with S.japonicum, treated with Ambilhar ( $100 \mathrm{mg} / \mathrm{kg}$ for 7 days) and Clonorchis sinensis.

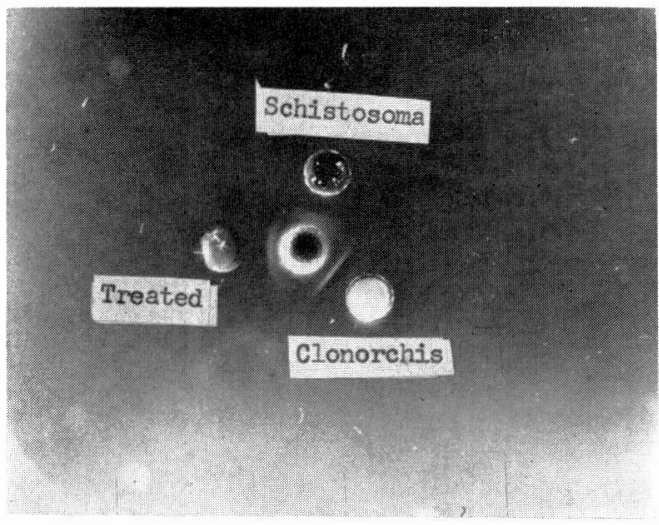

Schistosoma infected rabbit

Schistosoma treated with Ambilhar 100 $\mathrm{mg} / \mathrm{kg}$ for 7 days (Feb. 1968)

Clonorchis sinensis infected rabbit

The rest 4 cases which were ascertained to be infected by autopsy were negative even in the acid reactivation. It will be necessary to examine the dissociation method of antigen antibody complex.

Morishita's T. M. reaction was designed originally to find metabolites of worms in the intestinal tract of hosts using immunological methods. His method is as follows: antigen for the precipitin test was prepared from human feces. Ten $\mathrm{ml}$ of physiological saline was added to $5 \mathrm{~g}$ of human feces. After stirring well the fluid was incubated for 2 hours at $21^{\circ} \mathrm{C}$ and then centrifuged for five minutes at 10,000 r.p.m. to sediment out the coarse particles. The resulting supernatant fluid was adjusted to $\mathrm{pH} 3.5$ with $2 \% \mathrm{HCl}$. The vessel containing the fluid was then immersed in hot water $\left(100{ }^{\circ} \mathrm{C}\right)$ for one hour, centrifuged for five minutes at 10,000 r. p. m. The resultant supernatant fluid was adjusted to $\mathrm{pH} 7.0$ with $2 \% \mathrm{NaOH}$ solution, then strained through filter paper. After filtration the filtrate was ready for use as the antigen. Immune sera against Ascaris were prepared in male rabbits of approximately $2 \mathrm{~kg}$ weight. The animals were given an intravenous injection of $2 \mathrm{ml}$ of coelomatic fluid every 4 days. A precipitin titer of $1: 10,000$ to $1: 100,000$ was usually obtained after the third injection. Thus our antigen differs from the antigen used in the T.M. reaction. We observed that the treated rabbit gave a positive reaction. This rabbit was negative when tested by the urine precipitin test, precipitin ring test and circumoval precipitin test.

Feces of Clonorchis infected rabbits showed group reactions at a higher concentration of the antigen.

\section{REFERENCES}

1) Morishita, T. and Mabuchi, M. (1957): On T. M. reaction, a new diagnostic method for ascariasis by the precipitin test. Jap. J. exp. Med. 27, 1-4.

2) Okabe, K. and Tanaka, T. (1961): Urine precipitin reaction for schistosomiasis japonica. Kurume Med. J. 8, 24-37. 